\title{
Role of Social Partners for Work-Based Learning: Results of Surveys
}

\author{
Ilze Buligina ${ }^{1}$, Biruta Sloka ${ }^{2}$, Ināra Kantāne ${ }^{3}$, Anita Līce ${ }^{4}$ \\ ${ }^{1-4}$ University of Latvia, ${ }^{1}$ Jäzeps Vìtols Latvian Academy of Music, ${ }^{3}$ The University College of Economics and Culture
}

\begin{abstract}
Introduction of work-based learning (WBL) in Latvia has required new approaches in decision making of different stakeholders. Experience from countries with longstanding WBL tradition has shown the numerous advantages but also the challenges this approach presents. One of these challenges is the need for new forms and mechanisms of cooperation among the key stakeholders - policy makers, public administrators, employers, educators and social partners. The current paper analyses the results of scientific research in this field, as well as uses the empirical results of two surveys performed by the authors: a survey of public sector experts and a survey of employers in Latvia. In order to obtain detailed results, the evaluations of respondents on multiple aspects analysed in the surveys were evaluation in the scale 1-10. The data of both surveys have been analysed by descriptive analysis, crosstabulations and multivariate analysis - factor analysis. The results have indicated that the views of employers and social partners on the most of the key aspects of introduction and implementation of WBL are similar. However, a more profound analysis has to be performed in order to develop proposals or the most efficient approach to WBL.
\end{abstract}

Keywords - Employers, public administration, vocational education and training, work-based learning.

\section{INTRODUCTION}

A range of countries (Germany, Austria, Switzerland, the Netherlands, etc.) have been successfully addressing the issue of qualified labour force development by implementing workbased learning (WBL) approaches or apprenticeship schemes in vocational education and training (VET). Social partners, especially employers, are indispensable actors in implementing work-based learning. In Latvia the introduction of WBL on a small-scale started in 2013, with the aim of piloting various approaches to inform the policy decisions of the VET public administration at the national level. As the recent amendments of 2015 to the VET Law stipulate WBL as a form in the implementation of a VET programme, the public administrations are currently faced with a task to develop specific legal framework for implementing WBL at thee system level. As the employers are major stakeholders in the implementation of WBL, the conceptual approaches underlying the legal framework, among other issues, need to be informed by the opinions and interests of the employers. To this end, the authors carried out a survey (2014-2015) among employers to find out their opinions, i.e., on the relevance of certain centralised activities to promote the introduction of WBL in Latvia. The objective of the current paper is to compare the opinions of employers and of public administrators on the relevance of certain centralised activities to promote the introduction of WBL in Latvia.

The present paper provides an in-depth analysis of this particular aspect, as the interest and motivation of employers as key stakeholders is a factor determining the overall success of the process. In the light of a recent research based information note to the Cabinet of Ministers prepared by the Ministry of Economy of Latvia on the potential fiscal impact of various support measures to employers for facilitating their involvement in WBL, the analysis presented in this paper contributes to improved strategic decisions by public administrations in Latvia. The research results show that the employers are attributing almost equally high relevance to all of the proposed support activities. As these existing or potential support measures are under the responsibility of different public administrations in Latvia (Ministry of Education and Science, Ministry of Economics, Ministry of Welfare, Ministry of Finance and other), this leads to the conclusion that education and training processes are undergoing a gradual shift of focus and the overall paradigm, including a growing multiple public stakeholder responsibility for the education and training processes, especially since the employers have given the highest relevance (8.9 mean in a 110 point scale) to the proposed measure "Coordinated activities by public administration institutions in addressing training and employment issues". As in Latvia the education and training issues traditionally have been solely under the supervision of the Ministry of Education and Science, a need becomes apparent for a new research informed strategic approach for multiple stakeholder involvement in the implementation of VET and in particular the WBL for the training of a qualified and competitive work-force.

\section{METHODOLOGY OF RESEARCH}

The methods of research included the analysis of scientific publications and survey of experts involved in vocational education organisations. In the survey only experts with previous co-operation experience with vocational education providers were invited $(n=132)$. Regarding the employers only those were invited who had been actively involved in the piloting of work-based learning or in the provision of training praxis for VET students $(n=249)$. For data analysis of the both survey results, descriptive statistics was used: indicators of central tendency or location (arithmetic mean, mode, median) and indicators of variability (range, standard deviation, standard error of mean), as well as multivariate 
statistical analysis: factor analysis as well as correlation analysis.

\section{THEORETICAL BACKGROUND}

Academic researchers have extensively analysed the emergent European model in skill formation and have been comparing higher education and vocational training approaches in the Bologna and Copenhagen processes (Powel et al., 2012). They have been proposing an alternative to the American model, suggesting intergovernmental reform initiatives in Europe to promote a comprehensive model of skill formation. With regard to work-based learning the experience and approaches by different countries have been extensively analysed by academic researchers. In Denmark there are different research perspectives (Aakrog, 2006) in comparison with other countries (Biemans et al., 2009); in the Netherlands attention is devoted to changing pedagogic and didactic approaches in vocational education (De Bruijn, 2004). In general, changing approaches in the implementation of work-based learning is being stressed (Tynjälä, 2008), underlying the importance of the involvement of the representatives from the workplace and the role of the work environment (Billett, 2004). For the effective development of economic growth, the role of the transfer of knowledge paradigm in work-place learning has been analysed (Burns \& Paton, 2005).

Work-based learning requires for the development of new training/teaching methods (Leonard \& Talbot, 2009), as well as creates the need for academic research in the application of work-based learning and for the development of new research methods (Costley et al, 2010). The need for the adjustments of traditional research methods has also been underlined by (Walsh, 2011). According to Pittaway and Cope (2007), increase in interest in academic research and practical studies on workplace learning and flexible delivery to a certain extent is due to the awareness that workplace knowledge and skills contribute to enterprise and national competitiveness (Smith, 2003). Thus, according to Pittaway and Cope, also the relevance of simulating entrepreneurial learning increases (Pittaway \& Cope, 2007).

The orientation of vocational education towards competence-based education has led to fundamental changes in the work of vocational education teachers - e.g. in the Netherlands their teaching practices are directed towards innovative, competence-based approaches (Bruijn, 2012). Jon Talbot, Andy Lilley from the United Kingdom have performed research on the role of UK work-based learning tutors in facilitating formal research projects in the workplace (Talbot \& Lilley, 2014). Stav et al. stress the importance of discussing the result of such projects among researchers (Stav et al., 2011), thus contributing to improved social partners' involvement in work-based learning.

The studies on the role of apprenticeship approach in the United Kingdom (Brochman et al., 2010), the comparison of British apprenticeship with German system (Ryan \& Unwin, 2001) and stating academic research questions on creation are more effective. British vocational education system has contributed to proposing new ways in the choice at vocational education crossroads (Patel, 2012). Researchers in the UK have also addressed the issue on the expansion of the higher education in the context of the governmental expectations regarding the national economic competitiveness (James et al., 2013). The German apprenticeship system experience has also been studied and implemented in many countries, including the USA (Glover, 1996) with special attention to local youth and with regard to the labour supply problems encountered by local employers. The academic researchers have also explored to what extent first-line managers' (FLMs) support to employees' learning activities influences the learning outcomes and the transfer of training from a work-based vocational education and training (VET) programme (Ellström \& Ellsatröm, 2014).

Researchers have also been comparing the results gained in school-based learning and work-based learning (Alseddigi et al., 2012) and suggesting problem solution approaches taking into account different interests of involved stakeholders (Enthoven \& De Bruin, 2010). Extensive comparison of efficiency of school-based learning and work-based learning has been conducted by other researchers (Shaap et al., 2012), (Polidano \& Tabasso, 2014). The work-based learning advantages and disadvantages have been investigated by various involved stakeholders, including trainees, and results are being shared word wide (Sanda et al., 2014) with the help of scientific papers included in electronic data bases with scientific discussion approach and investigation.

In the context of the present paper, the research performed by international researchers regarding the influence of workbased learning on employability (Komariah, 2015) and the role and influence of social partners in vocational education (Bosch \& Charest, 2006) are of particular importance. Therefore, in the next chapter the most typical governance models for work-based learning in the countries with dual VET tradition will be analysed, as this creates a direct link with the empirical study performed by the authors.

\section{VET GOVERNANCE MODEL AND EMPLOYER INVOLVEMENT IN COUNTRIES WITH DUAL VET TRADITIONS}

Strong involvement of social partners is mentioned among the main success factors of dual VET system in Austria, Denmark, Germany, and Switzerland. Employers (and their associations) should consider training to be an investment in favour of competitiveness, productivity, and sustainable employment prospects, and thus could offer vocational training in a systematic and certifiable fashion (Eichhorst et al., 2015). In countries with long dual VET traditions, social partners participate in representative advisory boards, which assist in developing and maintaining curricula at the governmental and federal levels. Regional trade or occupational committees, or a combination of the two, undertakes implementation and monitoring of VET system (ibid).

Engaging with employers and social partners to increase the relevance of initial VET and to establish cooperation for providing work-based learning opportunities, including 
apprenticeship, also increases VET attractiveness in the eyes of young people who prefer a more practical path or the possibility of learning while working. Attractiveness of initial VET increases when qualifications have currency in the labour market (CEDEFOP, 2014).

The dual system depends on the employers' willingness to provide training placements, and this depends on their sense of ownership and control of the dual system (Steedman, 2005). It is likely that the employers' commitment to provide the necessary number of placements would decrease if their influence on the VET system were reduced by weakening the institutions of self-governance (Juul \& Jorgensen, 2011).

The governance of the dual VET system in Germany is characterised by an overall goal to meet the labour market needs and by strong partnership between state employers and trade unions. The governance elements and roles are the following (Hensen \& Hippach-Schneider, 2012):

- The Federal Government is responsible for designing the content of training for the occupations (in the dual system) it has recognized. The nationally binding recognition of the training occupations ensures that the basic principles agreed with industry and the Federal States (Länder) are taken into account and that training for a recognised occupation is only provided in accordance with the training regulations.

- In the German Federal Government, the Federal Ministry of Education and Research (BMBF) is responsible for general policy issues of vocational education and training, including the Vocational Training Act (Berufsbildungsgesetz, BBiG), legal supervision and funding of the Federal Institute for Vocational Education and Training (Bundesinstitut für Berufsbildung, BIBB), the core institution at the national level for consensus building between all parties involved in VET, and the implementation of programmes to improve vocational training.

- The recognition of the individual occupations requiring formal training is the task of the federal ministries responsible for the respective occupational field, in the vast majority of cases - the Federal Ministry of Economics and Technology (BMWi).

- The four-party Main Board (Hauptausschuss) advises the Federal Government on fundamental issues of in-company vocational training.

- Employers and trade unions play a central role in initiatives for change because the structure of vocational training should meet the demands of industry. Without the involvement of the Federal Government, the social partners, furthermore, agree on details of vocational training, particularly the amount of the allowance paid to trainees, within the framework of free collective bargaining. The chambers have been assigned public tasks in dual training, including the organisational, counselling and monitoring functions, e.g., registering the contracts, verifying the aptitude of companies, advising companies and trainees, organising exams.

In the Austrian dual VET system, the main governance elements are the following (Tritscher-Archan et al., 2012):
- The training content for every apprenticeship occupation is laid down in training regulations (for the company-based part) and curricula (for the school-based part). The incompany curriculum is adopted within the framework of the training regulation by the Federal Ministry of Economy, Family and Youth (BMWFJ) of Germany.

- Initiatives to adjust existing or introduce new incompany curricula are frequently taken by companies or social partners. The Federal Advisory Board on Apprenticeship (Bundesberufsausbildungsbeirat, BABB) - a body which comprises social partner representatives and advises the Ministry of Economy in apprenticeship issues - also introduces proposals or prepares expert opinions about reform proposals. The actual designing of in-company curricula and thus the orientation towards qualification requirements is, as a rule, conducted by $\mathrm{BABB}$ subcommittees or the educational research institutes of the social partners: the Institute for Research on Qualifications and Training of the Austrian Economy (ibw) on the employers' side and the Austrian Institute for Research on Vocational Training (öibf) on the employees' side.

- Very important role of organising the apprenticeships is assigned to the regional economic chambers. Their Apprenticeship Offices act as apprenticeship authorities of the first instance. They examine the training enterprises' suitability to provide apprenticeship training; they are responsible for examining and recording apprenticeship contracts. In principle it is their task to provide wide-ranging counselling to apprentices and training enterprises in all matters concerning apprenticeship (Federal Ministry of Science, Research and Economy of Austria, 2014).

In Denmark, the social partners have had a decisive influence on the VET system since the 1930s through the principle of occupational self-governance, and this is regarded to be a major reason why the dual system has survived until today (Juul \& Jorgensen, 2011). The trade committees (de faglige udvalg) where social partners are represented in equal numbers define the content of the education and training programmes, including the division between practical training and school-based learning and, inter alia, seek to ensure that IVET is in line with labour market needs (Ecorys et al., 2013). Currently, however, increased pressure from growing government intervention aimed at integration of the VET system within general educational policy poses a new challenge to apprenticeship system questioning its basic position in VET system (Juul \& Jorgensen, 2011).

Another precondition for employers to participate in workbased learning and to fund in-company training as well as remuneration to apprentices is cost-effectiveness of apprenticeships. The financing of apprenticeship is complex and vitally important for its viability. When investment in apprenticeship leads to a commensurate reward, an incentive to undertake training is present. If cost sharing reflects benefitsharing then the outcome will be a sufficient supply of places and a corresponding demand from young people (Steedman, 2012). 
Comparative cost-benefit analysis in Germany and Switzerland shows that, during the apprenticeship period, German firms incur - on average - net costs, while Swiss firms experience net benefits. The difference in the net costs of training apprentices from the firm's perspective between Germany and Switzerland amounts to 25000 EUR for a threeyear training programme (Dionisius et al., 2008). The difference in returns on apprenticeships for firms in the two countries appears mainly due to the relevant benefits rather than costs and can be explained by a higher share of productive tasks being allocated to apprentices in Switzerland and by the differences in relative wages with respect to regular employment (with higher differentials in Switzerland). The large supply of apprenticeship placements in German firms, which on average incur a net cost during training, can be explained by higher productivity of trained apprentices later on (Steedman, 2012). At the same time, cost-benefit analysis of apprenticeships in the UK has shown that there is a large net social benefit, reflecting that apprenticeships are an investment with positive returns in the longer term for all stakeholders involved. It shows that by taking in apprentices, employers assume a cost in the short-run, but that there is a net benefit in the longer term (Ecorys et al., 2013).

To outweigh the costs for employers and to encourage them to participate in apprenticeship-type training, a number of public subsidies are available to support training companies in different countries. Short-term targeted government subsidies have been used to compensate companies for the additional cost of taking "hard to place" apprentices. Even some training regulations are relaxed to lower employers' costs and to ensure that increased numbers of apprenticeship places are provided (Steedman, 2012).

For example, in Austria, the training company can apply for basic subsidisation at the end of every apprenticeship year. For the first apprenticeship year, there is available a subsidy of three gross apprenticeship remunerations pursuant to the respective collective agreement; for the second year - two remunerations; for the third and fourth year - one remuneration (Federal Ministry... - bmwfw, 2014). This support is meant to compensate to the employers the unproductive time of apprentice at the training company. Additional support is available for start-up companies, for companies training for the first time or after the break, for training young women in occupations with a low share of women, youths disadvantaged on the labour market, participants in integrative IVET systems and adults with employment problems due to lacking qualifications (ibid.).

In Germany and Switzerland public funding is largely limited to the provision of part-time vocational education (Ryan et al., 2011). At the same time, there are special programmes for disadvantaged youth, and accommodation benefits for apprentices who live away from home, as well as to support training in the private training centres. For example, in Berlin, there is a financial support for firms which give an apprenticeship position to disadvantaged youths; $30 \%$ of remuneration in the first and second year; $70 \%$ in the third year (max. 10000 EUR), as well as the support for firms employing female apprentices in male dominated occupations, apprentices from bankrupt or closed-down firms as well as who are single parents. There is also a financial support of "combined training": 37.50 EUR/day to a partner firm cooperating with the firm providing vocational training (Dombrowski, 2015), targeting SMEs which cannot ensure full in-company training for the occupational requirements.

As seen from the analysis above, the multi-stakeholder governance model is characteristic of dual VET systems. Usually, the ministry responsible for economic development has a particular role to play along with the ministry responsible for education. Particular roles are assigned to the federal and regional level governments, and the social partners and chambers of commerce are involved in VET organisational model with particular role and responsibility, mainly regarding initiating changes to occupational requirements and practical organisation of apprenticeships, in this way serving as service providers to companies and intermediaries between the policy makers and users of the system. Involvement of different stakeholders is also needed to develop policy for work-based learning implementation in countries without this experience, as it is related not just to the education policy, but also to employment, economic and financial policy of the country.

\section{EMPIRICAL RESEARCH RESULTS}

In the factor analysis of social partners' evaluations on the question "What centralised activities do you consider relevant for successful implementation of WBL in Latvia?" several aspects were asked to evaluate in scale 1-10. Two complex factors F1 and F2 were identified by extraction method of principal component analysis in three iterations using the rotation method - Varimax with Kaiser normalisation. Complex factor F1 was named "state organisational and financial support factor" where initial factors had the strongest correlation with the first complex factor being more than 0.5 and complex factor F2 was named "information and education provision factor" where initial factors had the strongest correlation with the second complex factor being more than 0.5. Results of factor analysis of social partners' evaluations are reflected in Table I.

The main statistical indicators of evaluations of social partners' survey are included in Table II. Data of Table II show that the average evaluations for all statements were very high: the arithmetic means for all statements were not less than 7.4; the mode for all statements was 10 (the most often mentioned evaluation by respondents), the median for all statements was greater than 8 except for the statements "individual consultations with the employers" and "information campaigns in mass media" (it means that half of respondents or $50 \%$ gave evaluations greater than 8 and half of respondents or $50 \%$ gave evaluations smaller than 8 ). The main differences in respondent evaluations were for the statement "information campaigns in mass media" which had the highest variability of evaluations by the respondents characterised by indicators of variability or dispersion: standard deviation as well as by standard error of mean. 
TABLE I

COMPLEX FACTORS ON SOCIAL PARTNERS’ EVALUATIONS ON THE QUESTION “WHAT CENTRALISED ACTIVITIES Do YOU CONSIDER RELEVANT FOR SUCCESSFUL IMPLEMENTATION OF WBL IN LATVIA?"

\begin{tabular}{|c|c|c|}
\hline \multirow{2}{*}{ Initial factors } & \multicolumn{2}{|c|}{ Complex Factors } \\
\hline & F1 & $\mathrm{F} 2$ \\
\hline Tax reduction for enterprises involved in WBL & 0.852 & 0.081 \\
\hline Improved legal framework & 0.776 & 0.185 \\
\hline Material support by the state to the mentors working with trainees at an enterprise & 0.753 & 0.335 \\
\hline Compensation to employers for covering trainees' expenditure on transport fees, specialised clothing etc. & 0.688 & 0,363 \\
\hline Possibility to be flexible in the provision of the theoretical studies according to the employers' needs & 0.587 & 0.343 \\
\hline Support to the enterprise during the organisation of the work placement & 0.568 & 0.498 \\
\hline Pedagogical / methodological support to mentors working with trainees at an enterprise & 0.135 & 0.823 \\
\hline Individual consultations with the employers & 0.176 & 0.789 \\
\hline Information campaigns in mass media & 0.356 & 0.678 \\
\hline Coordinated activities by public administration institutions in addressing training and employment issues & 0.336 & 0.606 \\
\hline \multicolumn{3}{|l|}{$\begin{array}{l}\text { Extraction Method: Principal Component Analysis. } \\
\text { Rotation Method: Varimax with Kaiser Normalization. }\end{array}$} \\
\hline a. Rotation converged in 3 iterations. & & \\
\hline
\end{tabular}

TABLE II

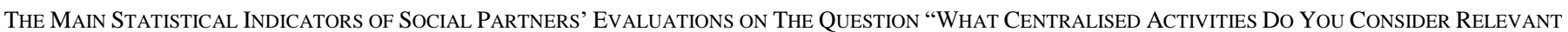
FOR SUCCESSFUL IMPLEMENTATION OF WBL IN LATVIA?"

\begin{tabular}{|c|c|c|c|c|c|c|c|c|}
\hline & Mean & $\begin{array}{c}\text { Standard } \\
\text { Error of Mean }\end{array}$ & Median & Mode & $\begin{array}{l}\text { Standard } \\
\text { Deviation }\end{array}$ & Range & Minimum & Maximum \\
\hline $\begin{array}{l}\text { Coordinated activities by public administration } \\
\text { institutions in addressing training and employment issues }\end{array}$ & 8.9 & 0.15 & 10 & 10 & 1.64 & 9 & 1 & 10 \\
\hline $\begin{array}{l}\text { Support to the enterprise during the organisation of the } \\
\text { work placement }\end{array}$ & 8.7 & 0.17 & 9 & 10 & 1.84 & 7 & 3 & 10 \\
\hline Improved legal framework & 8.6 & 0.16 & 9 & 10 & 1.74 & 9 & 1 & 10 \\
\hline Tax reduction for enterprises involved in WBL & 8.5 & 0.20 & 10 & 10 & 2.19 & 9 & 1 & 10 \\
\hline $\begin{array}{l}\text { Possibility to be flexible in the provision of the } \\
\text { theoretical studies according to the employers' needs }\end{array}$ & 8.4 & 0.14 & 9 & 10 & 1.55 & 7 & 3 & 10 \\
\hline $\begin{array}{l}\text { Material support by the state to the mentors working with } \\
\text { trainees at an enterprise }\end{array}$ & 8.4 & 0.19 & 9 & 10 & 2.04 & 9 & 1 & 10 \\
\hline $\begin{array}{l}\text { Pedagogical / methodological support to mentors working } \\
\text { with trainees at an enterprise }\end{array}$ & 8.3 & 0.16 & 9 & 10 & 1.77 & 7 & 3 & 10 \\
\hline $\begin{array}{l}\text { Compensation to employer's for covering trainees } \\
\text { expenditure on transport fees, specialised clothing etc. }\end{array}$ & 8.2 & 0.20 & 9 & 10 & 2.15 & 9 & 1 & 10 \\
\hline Individual consultations with the employers & 8.1 & 0.17 & 8 & 10 & 1.82 & 8 & 2 & 10 \\
\hline Information campaigns in mass media & 7.4 & 0.22 & 8 & 10 & 2.35 & 9 & 1 & 10 \\
\hline
\end{tabular}

Source: Authors' calculations based on public sector expert survey conducted by Ilze Buligina in 2014, 2015 ( $n=132$ ), evaluation scale 1-10, where 1 - not significant; 10 - very significant

The next main differences in respondent evaluations were for the statement "tax reduction for enterprises involved in WBL" although the mode and the median for this statement were the highest possible, i.e., 10.

The main statistical indicators of entrepreneurs and sectoral experts' evaluations are reflected in Table III. The average entrepreneurs and sectoral experts' evaluations on the question "What centralised activities do you consider relevant for successful introduction of WBL in Latvia?" for all statements were very high: the arithmetic means for all statements were not less than 7.2; mode for almost all statements (except for evaluations of statement "information campaigns in mass media") was 10 (the most often mentioned evaluation by experts), median for all statements was greater than 8 except for the statements "individual consultations with the employers" and "information campaigns in mass media" (half of respondents gave evaluations greater than 8 and half of respondents gave evaluations less than 8 ). The main differences in respondent evaluations were for the statement "information campaigns in mass media" which had the biggest standard deviation. 
TABLE III

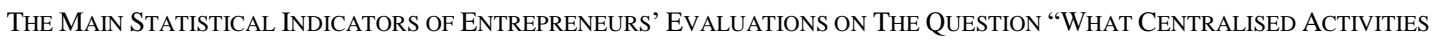
DO YOU CONSIDER RELEVANT FOR SUCCESSFUL IMPLEMENTATION OF WBL IN LATVIA?"

\begin{tabular}{|c|c|c|c|c|c|c|c|c|}
\hline & Mean & $\begin{array}{c}\text { Standard } \\
\text { Error of } \\
\text { Mean }\end{array}$ & Median & Mode & $\begin{array}{l}\text { Standard } \\
\text { Deviation }\end{array}$ & Range & Minimum & Maximum \\
\hline $\begin{array}{l}\text { Support to the enterprise during the organisation of the } \\
\text { work placement }\end{array}$ & 9.0 & 0.11 & 9 & 10 & 1.53 & 9 & 1 & 10 \\
\hline Tax reduction for enterprises involved in WBL & 9.0 & 0.13 & 10 & 10 & 1.86 & 9 & 1 & 10 \\
\hline $\begin{array}{l}\text { Possibility to be flexible in the provision of the theoretical } \\
\text { studies according to the employers' needs }\end{array}$ & 8.8 & 0.11 & 9 & 10 & 1.60 & 9 & 1 & 10 \\
\hline $\begin{array}{l}\text { Material support by the state to the mentors working with } \\
\text { trainees at an enterprise }\end{array}$ & 8.8 & 0.11 & 9 & 10 & 1.63 & 9 & 1 & 10 \\
\hline Improved legal framework & 8.7 & 0.12 & 9 & 10 & 1.67 & 8 & 2 & 10 \\
\hline $\begin{array}{l}\text { Compensation to employer's for covering trainees } \\
\text { expenditure on transport fees, specialised clothing etc. }\end{array}$ & 8.7 & 0.13 & 9 & 10 & 1.93 & 9 & 1 & 10 \\
\hline $\begin{array}{l}\text { Coordinated activities by public administration } \\
\text { institutions in addressing training and employment issues }\end{array}$ & 8.6 & 0.13 & 9 & 10 & 1.86 & 9 & 1 & 10 \\
\hline $\begin{array}{l}\text { Pedagogical/ methodological support to mentors working } \\
\text { with trainees at an enterprise }\end{array}$ & 8.4 & 0.13 & 9 & 10 & 1.92 & 8 & 2 & 10 \\
\hline Individual consultations with the employers & 7.9 & 0.13 & 8 & 10 & 1.92 & 7 & 3 & 10 \\
\hline Information campaigns in mass media & 7.2 & 0.16 & 8 & 8 & 2.23 & 9 & 1 & 10 \\
\hline
\end{tabular}

Source: Authors' calculations based on entrepreneur survey conducted by Ilze Buligina in 2014, 2015 (n=249), evaluation scale 1-10, where 1 - not significant; 10 - very significant

The next main differences in expert evaluations were for the statement "tax reduction for enterprises involved in WBL" although the mode and the median for this statement were the highest possible.

Results of the factor analysis of entrepreneurs and sectoral experts' evaluations are reflected in Table IV.

TABLE IV

COMPLEX FACTORS ON ENTREPRENEURS' EVALUATIONS ON THE QUESTION "What CENTRALISED ACTIVITIES Do You CONSIDER ReleVANT FOR SUCCESSFUL IMPLEMENTATION OF WBL IN LATVIA?"

\begin{tabular}{|c|c|c|}
\hline \multirow[t]{2}{*}{ Initial factors } & \multicolumn{2}{|c|}{$\begin{array}{l}\text { Complex } \\
\text { Factors }\end{array}$} \\
\hline & F1 & F2 \\
\hline Tax reduction for enterprises involved in WBL & 0.827 & 0.160 \\
\hline $\begin{array}{l}\text { Material support by the state to the mentors working with } \\
\text { trainees at an enterprise }\end{array}$ & 0.785 & 0.202 \\
\hline $\begin{array}{l}\text { Compensation to employers for covering trainees } \\
\text { expenditure on transport fees, specialised clothing etc. }\end{array}$ & 0.771 & 0.150 \\
\hline $\begin{array}{l}\text { Support to the enterprise during the organisation of the } \\
\text { work placement }\end{array}$ & 0.605 & 0.196 \\
\hline Information campaigns in mass media & -0.218 & 0.774 \\
\hline $\begin{array}{l}\text { Pedagogical/ methodological support to mentors working } \\
\text { with trainees at an enterprise }\end{array}$ & 0.271 & 0.681 \\
\hline Individual consultations with the employers & 0.315 & 0.654 \\
\hline Improved legal framework & 0.418 & 0.618 \\
\hline $\begin{array}{l}\text { Coordinated activities by public administration } \\
\text { institutions in addressing training and employment issues }\end{array}$ & 0.251 & 0.612 \\
\hline $\begin{array}{l}\text { Possibility to be flexible in the provision of the theoretical } \\
\text { studies according to the employers' needs }\end{array}$ & 0.197 & 0.602 \\
\hline \multicolumn{3}{|c|}{$\begin{array}{l}\text { Extraction Method: Principal Component Analysis. Rotation Method: } \\
\text { Varimax with Kaiser Normalization. a. Rotation converged in } 3 \text { iterations. }\end{array}$} \\
\hline
\end{tabular}

As a result of factor analysis of entrepreneurs and sectoral experts' evaluations on the question "What centralised activities do you consider relevant for successful introduction of WBL in Latvia?", two complex factors F1 and F2 were identified. Complex factor F1 was named "administrative support and financial support factor" where initial factors had the strongest correlation with the first complex factor being more than 0.5 , and complex factor F2 was named "WBL organisation factor" where initial factors had the strongest correlation with the second complex factor being more than 0.5 . In general, the results of evaluations by the entrepreneurs are similar with the results of evaluations of social partners although the correlations of the initial factors with the respective complex factors are not exactly the same, but more alike as it was mentioned in interviews with policy makers before the both mentioned and analysed surveys.

Factor analysis of both surveys has shown alike results, which means that both respondent groups have alike viewpoints on these highly important issues, and this provides the basis for public administrators to propose policy solutions for ensuring preparation of qualified work-force.

\section{CONCLUSION}

In the globally fast changing labour market developments new approaches are needed for the development of a competitive labour force. Work-based learning is increasingly being considered as an optimal solution to address the problem. The experience of the countries with traditional dual VET systems can provide useful insights but cannot provide universal solutions. Therefore, countries need to develop their own solutions when introducing work-based learning elements in their VET systems. 
Social partners have a key role in the implementation of work-based learning; therefore, the public administrations responsible for VET have to work in close co-operation with social partners and employers for preparing a competitive labour force via work-based learning approaches. For this reason, the opinions of employers and public sector experts need to be obtained and analysed in order to take the most appropriate decisions at the system level.

Results of factor analysis of entrepreneurs and public experts' evaluations on the statement "What centralised activities do you consider relevant for successful introduction of WBL in Latvia?" allowed identifying two complex factors for the both analysed groups: for social partners: F1 organisational and financial support and complex factor F2 information and education provision factor; and on the basis of entrepreneurs and sectoral experts' evaluations two complex factors F1 and F2 were identified, where complex factor F1 was named "administrative support and financial support factor" and complex factor F2 was named "WBL organisation factor". The research results showed that almost equally high relevance was attributed to all of the proposed support activities. The differences by the both analysed groups of initial factor and complex factor correlations were only for statements "improved legal framework" and "possibility to be flexible in the provision of the theoretical studies according to the employers' needs".

The analysis of the entrepreneur survey results led to an important conclusion regarding the responsibilities of public bodies in the implementation of VET reforms in relation to workbased learning. As the proposed support measures analysed in the survey refer to the field of competence of different public bodies (including ministries), it becomes apparent that a multiple stakeholder governance model should be considered for developing and implementing a national system for work-based learning (WBL), taking into account experience of countries with dual vocational education and training (VET) traditions. This conclusion implies the gradual change of paradigm in the development of labour force by the VET system, and this in its turn requires discussion and subsequent development of new institutional mechanisms to ensure the governance and functioning of such multi-stakeholder approach, especially with regard to co-operation of public administrations in different sectors of the national economy.

\section{ACKNOWLEDGEMENT}

The paper has been supported by the National Research Program 5.2. EKOSOC-LV

\section{REFERENCES}

Alseddigi, M., Mishra, R. \& Pilsaru, C. (2012). An Evaluation Quality Framework for Analysing School-Based Learning (SBL) to Work-Based Learning (WBL) Transition Module. The $25^{\text {th }}$ International Congress on Condition Monitoring and Diagnostic Engineering (COMADEM), University of Huddersfield, England, 10. http://dx.doi.org/10.1088/1742$\underline{6596 / 364 / 1 / 012118}$

Aarkrog, V. (2005). Learning in the Workplace and the Significance of School-Based Education: A Study of Learning in Danish Vocational Education and Training Programme. International Journal of Lifelong Education, 24(2), 137-147.

http://dx.doi.org/10.1080/02601370500056268
Biemans, H., Wesselink, R., Gulikers., J., Schaafsma, S., Verstegen, J. \& Mulder, M. (2009). Towards Competence-Based VET: Dealing with the Pitfalls. Journal of Vocational Education and Training, 61(3), 267-286. http://dx.doi.org/10.1080/13636820903194682

Billett, S. (2004). Workplace Participatory Practices. Conceptualizing Workplaces as Learning Environments. Journal of Workplace Learning, 16(6), 312-324. http://dx.doi.org/10.1108/13665620410550295

Billett, S. (2001). Vocational Educators: Understanding Practice at Work. In C. Velde (Ed.), International Perspectives on Competence in the Workplace. Research, Policy and Practice (pp. 41-65). Dordrecht: Springer Netherlands. http://dx.doi.org/10.1007/978-94-010-0742-9 4

Bosch, G. \& Charest, J. (2006). Vocational Training Systems in Ten Countries and the Influence of the Social Partners. International Scientific Conference - IIRA 14th World Congress, Lima, Peru.

Brockman, M., Clarke, L. \& Winsch, C. (2010). The Apprenticeship Framework in England: A New Beginning or a Continuing Sham? Journal of Education and Work, 23(2), 111-127. http://dx.doi.org/10.1080/13639081003627439

Bruijn, E. (2012). Teaching in Innovative Vocational Education in the Netherlands. Teachers and Teaching, 18(6), 637-653. http://dx.doi.org/10.1080/13540602.2012.746499

Burns, G. R. \& Paton, R. R. (2005). Supported Workplace Learning: a Knowledge Transfer Paradigm. Policy Futures in Education, 3(1), 50-61. http://dx.doi.org/10.2304/pfie.2005.3.1.9

Costley, C., Elliott, G. \& Gibbs, P. (2010). Doing Work-based Research: Approaches to Enquiry for Insider-Researchers, London: Sage, 196. http://dx.doi.org/10.4135/9781446287880

De Bruijn, E. (2004). Changing Pedagogic and Didactic Approaches in Vocational Education in the Netherlands. From Institutional Interests to Ambitions of Students. European Journal of Vocational Training, 31(1), 23-37. Retrieved from http://files.eric.ed.gov/fulltext/EJ734137.pdf

Dionisius, R., Muehlemann, S., Pfeifer, H., Walde, G., Wenzelmann, F. \& Wolter, S. C. (2008). Cost and Benefit of Apprenticeship Training: A Comparison of Germany and Switzerland. IZA DP No. 3465. Retrieved from http://ftp.iza.org/dp3465.pdf

Dombrowski, R. (2015). Vocational Education Policy in Berlin, Challenges and Strategies. Presentation at the learning visit organised by LDDK and ABB-ATC, meeting with the Senate department for labour, integration and women's issues of Berlin, February 2015.

Ecorys, IES, IRS, (2013). Apprenticeship and Traineeship Schemes EU27: Key Success Factors. A Guidebook for Policy Planners and Practitioners. Retrieved from http://ec.europa.eu/education/policy/vocational-policy/ doc/alliance/apprentice-trainee-success-factors_en.pdf

Eichhorst, W., Rodrigues-Planas, N., Schmidl, R. \& Zimmermann, K. (2015). A Roadmap to Vocational Education and Training in Industrialized Countries. ILR Review, 68(2), 314-337. http://dx.doi.org/10.1177/0019793914564963

Ellström, E. \& Ellström, P. E. (2014). Learning Outcomes of a Work-Based Training Programme: The Significance of Managerial Support. European Journal of Training and Development, 38(3), 180-197. http://dx.doi.org/10.1108/EJTD-09-2013-0103

Enthoven, M. \& De Bruijn, E. (2010). Beyond Locality: the Creation of Public Practice Based Knowledge through Practitioner Research in Professional Learning Communities and Communities of Practice. Educational Action Research Journal, 18(2), 289-298. http://dx.doi.org/10.1080/09650791003741822

European Centre for the Development of Vocational Training (Cedefop) (2014). Attractiveness of initial vocational education and training: identifying what matters. Luxembourg: Publications Office of the European Union.

Federal Ministry of Science, Research and Economy of Austria (bmwfw), (2014). Apprenticeship. Dual Vocational Education and Training in Austria, Modern Training with a Future. Retrieved from

http://www.en.bmwfw.gv.at/Vocationaltraining/Apprenticeshipsandvocati onaltraining/Documents/NEU_HP_Apprenticeship.pdf

Glover, R. W. (1996). The German Apprenticeship System: Lessons for Austin, Texas. Annals, AAPSS, 544, 83-94. http://dx.doi.org/10.1177/0002716296544001007

Hensen, K. A. \& Hippach-Schneider, U. (2012). Germany. VET in Europe Country report. CEDEFOP REFERNET. Retrieved from http://www.cedefop.europa.eu/EN/Information-services/vet-in-europecountry-reports.aspx

James, S., Warhurst, C., Tholen, G. \& Commander, J. (2013). What we Know and What We Need to Know about Graduate Skills. Work, Employment and Society, 27(6), 952-963. http://dx.doi.org/10.1177/0950017013500116 
Juul, I. \& Jorgensen, C. H. (2011). Challenges for the Dual System and Occupational Self-Governance in Denmark. Journal of Vocational Education and Training, 63(3), 289-303. http://dx.doi.org/10.1080/13636820.2011.560393

Komariah, K. (2015). The Role of Work-Based Learning in Building Employability Skills of Vocational Education Students. Proceedings of the $3^{\text {rd }}$ UPI International Conference of Technical and Vocational Education and Training (Vol. 14, pp. 110-113). http://dx.doi.org/10.2991/ictvet-14.2015.25

Leonard, D. \& Talbot, J. (2009). The Situated Learning of Work Based Learning Tutors: Developing New Work Based Learning Pathways. In D. Young, J. Garnett (Eds.), Work Based Learning Futures 111, (pp. 3 20). University Awards Council (UVAC), Bolton.

Nixon, I., Smith, K., Stafford, R. \& Camms, S. (2006). Work Based Learning. Illuminating the Higher Education Landscape. Final Report, London: Higher Education Academy (HEA), pp. 561-575.

Patel, R. (2012). Are We There Yet? Vocational Education at Crossroads. Local Economy, 27(3), 227-231. http://dx.doi.org/10.1177/0269094211434467

Pittaway, L. \& Cope, J. (2007). Simulation Entrepreneurial Learning, Integrating Experimental and Collaborative Approaches to Learning. Management Learning, 38(2), 211-233. http://dx.doi.org/10.1177/1350507607075776

Polidano, C. \& Tabasso, D. (2014). Making it Real: the Benefits of Workplace Learning in Upper-Secondary Vocational Education and Training Courses. Economics of Education Review, 42, 230-146. http://dx.doi.org/10.1016/j.econrdurev.2014.06.003

Powell, J. J. W., Bernhard, N. \& Graf, L. (2012). The Emergent European Model in Skill Formation: Comparing Higher Education and Vocational Training in the Bologna and Copenhagen Processes. Sociology of Education, 85(3), 240-258. http://dx.doi.org/10.1177/0038040711427313

Ryan, P. \& Unwin, L. (2001). Apprenticeship in the British 'Training Market'. National Institute Economic Review, 178(1), 99-114. http://dx.doi.org/10.1177/002795010117800114

Ryan, P., Wagner, K., Teuber, S. \& Backes-Gellner, U. (2011). Financial aspects of Apprenticeship Training in Germany, Great Britain and Switzerland. Retrieved from http://www.boeckler.de/pdf/p_arbp_241.pdf

Sandal, A. K., Smith, K. \& Wangensten, R. (2014). Vocational Students Experiences with Assessment in Workplace Learning. Vocations and Learning, 7(2), 241-261. http://dx.doi.org/10.1007/s12186-014-9114-z

Schaap, H., Baartman, L. \& Bruijn, E. (2012). Students’ Learning Processes during School - based Learning and Workplace Learning in Vocational Education: a Review. Vocations and Learning, 5(2), 99-117. http://dx.doi.org/10.1007/s12186-011-9069-2

Smith, P. J. (2003). Workplace Learning and Flexible Delivery. Review of Educational Research, 73(1), 53-88. http://dx.doi.org/10.3102/00346543073001053

Stav, J. B., Thorseth, T. M. \& Stockert, R. (2011). Experiences with Innovative Tools and Services for Vocational Education and Training in Quality Assurance. The $3^{\text {rd }}$ International Conference on Education and New Learning Technologies, Proceedings, Barcelona, Spain, (pp. 67856790).

Steedman, H. (2005). Apprenticeship in Europe: 'Fading' or flourishing? CEP Discussion Paper No. 710. London: Centre for Economic Performance. Retrieved from http://eprints.lse.ac.uk/19877/

Steedman, H., (2012). Overview of apprenticeship systems and issues - ILO contribution to the G20 Task Force on Employment. International Labour Office, Skills and Employability Department, Geneva. http://dx.doi.org/10.2139/ssrn.2283123

Talbot, J. \& Lilley, A. (2014). Approaches to Supervising Work-Based Learning Students' Workplace Research, Higher Education, Skills and Work-Based Learning, 4(1), 44-65. http://dx.doi.org/10.1108/HESWBL08-2012-0032

Tritscher-Archan, S., Nowak, S., Weiß, S. \& Grün, G. (2012). Austria, VET in Europe - Country report. Retrieved from Cedefop Refernet website: http://www.cedefop.europa.eu/en/publications-and-resources/countryreports/austria-vet-europe-country-report-2012

Tynjälä, P. (2008). Perspectives into Learning at the Workplace. Educational Research Review, 3, 130-154. http://dx.doi.org/10.1016/j.edurev.2007.12.001

Walsh, A. (2011). Beyond a Naturally Occurring Ethnography: the WorkBased Researcher. Higher Education, Skills and Work-Based Learning, 1(1), 38-51. http://dx.doi.org/10.1108/20423891111085384
Workman, B. (2007). Casing the Joint: Exploration by Insider-Researchers Preparing for Work-Based Projects. Journal of Workplace Learning, 19(3), 146-160. http://dx.doi.org/10.1108/13665620710735620

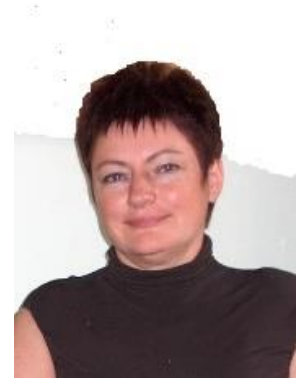

Ilze Buligina, Dr. admin. received the MA degree (Cum Laude) from Maastricht University, the Netherlands, in 2010 and the doctoral degree Dr. admin. at the University of Latvia in 2015. Her field of study is public administration and vocational education and training (VET). She is currently working at the Ministry of Education and Science, Latvia and has been involved in several working groups of the European Commission. She has also coordinated and managed several EU projects. Her research interests include public administration, governance, labour force training by VET system. She has received the Top $3 \%$ Student Award of Maastricht University in 2010 .

Address: Faculty of Economics and Management, University of Latvia, 5 Aspazijas Blvd., Riga, LV-1050, Latvia

Phone: + 37129478176

E-mail: ilze.buligina@gmail.com

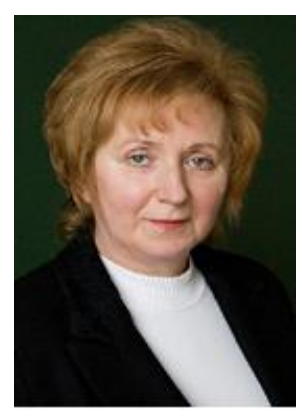

Biruta Sloka, Dr. oec., is a Professor at the University of Latvia. She has participated in several research projects, headed the Euro Faculty Riga Centre. She is a Member of the Latvian Association of Econometrists, Member of Association of Professors of Higher Education of Latvia and the President of the Latvian Association of Statisticians.

Address: Faculty of Economics and Management, University of Latvia, 5 Aspazijas Blvd., Riga, LV-1050, Latvia

Phone: + 37129244966

E-mail: Biruta.Sloka@lu.lv

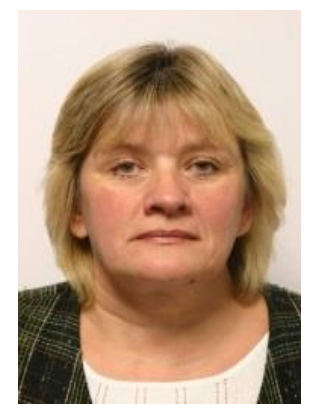

Ināra Kantāne, Dr. admin. received the Master's degree in Economics (Mg. oec.) in 2003 and Dr. sc. admin. degree in 2013. She is a Researcher at the University of Latvia and an Associate Professor at the University College of Economics and Culture. Her field of study is small and medium-sized business, factors influencing business development, employment. She has been a Lecturer and Database Engineer at the Faculty of Economics and Management of the University of Latvia, Associate Professor at the University College of Economics and Culture, Researcher in ESF, ERAF projects and in the projects of the University of Latvia. She is a Member of the Latvian Association of Statisticians.

Address: Faculty of Economics and Management, University of Latvia, 5 Aspazijas Blvd., Riga, LV-1050, Latvia

Phone: + 37129491763

E-mail: Inara.Kantane@lu.lv

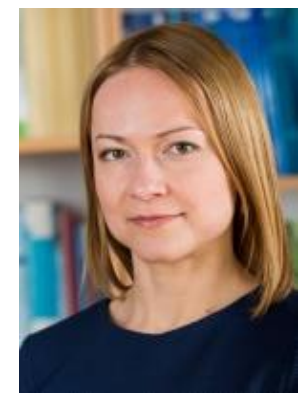

Anita Līce received the Master's degree in Education Science from the University of Latvia where she continues her $\mathrm{PhD}$ studies in Education Management. She is responsible for the field of Education and Employment at the Employers' Confederation of Latvia (LDDK) since 2010. She is also a Member of the Register Committee of the European Quality Assurance Register for Higher Education (EQAR) and of the Advisory Committees on Vocational Education and Training to the European Commission. She was an Adviser to the Minister of Education and Science Ms Marite Seile. Her field of interest is employability and education - labour market links.

Address: Employers' Confederation of Latvia, 25-3 Baznicas St., Riga, LV-1010, Latvia

Phone: +371 29199276

E-mail: Anita.Lice@gmail.com 